\title{
Fate and distribution of toxic heavy metals in some marine organisms from the eastern Adriatic coast
}

\author{
I. Vukadin, T. Zvonarić \& N. Odžak \\ Institute of Oceanography and Fisheries; 58000 Split, Croatia
}

\begin{abstract}
The paper reports on levels of heavy metals in some organisms from the eastern Adriatic coast and polluted areas near a big urban centre (Split area). Surprisingly high $\mathrm{Hg}$ and MeHg concentrations were found in sea bream (Pagellus erythrinus) and striped mullet (Mullus barbatus) from the south-eastern part of the Adriatic. The reason for the high levels are probably geochemical anomalies. Studies of total and organic mercury content in bivalves have also shown that the gills and hepatopancreas had high levels of accumulated mercury. Our results have shown that fish contain significantly higher concentrations of $\mathrm{MeHg}$ than mussel. High concentrations of these elements in fish may be a consequence of the methylation process in the visceral organs. Bacterial activity in the intestinal contents is most likely to be responsible for this methylation (Rudd et al., 1980).
\end{abstract}

\section{INTRODUCTION}

Intensive population expansion along the coast of the Adriatic Sea (particularly during summer) and a rapid development of industry and technology results in an increase of production of waste which unfortunately is in the end discharged into the sea. Even though initially the sea seemed to be capable of indefinately receiving waste disposal, persistent discharges into the sea have generated considerable concern for the continuance of normal functions of those coastal areas which have undergone serious damage due to increasing pollution.

Long term studies of metals ( $\mathrm{Hg}, \mathrm{As}, \mathrm{Se}, \mathrm{Cu}, \mathrm{Cd}, \mathrm{Sb}$ and $\mathrm{Zn}$ ) in seawater, sediments and some marine organisms in the coastal area of the middle and southern Adriatic have shown that areas in the vicinity of industrial centres are the most affected since industry is the principal source of pollution by these microelements (Stegnar et al., 1981; Vukadin, 1980). In our studies, special attention was given to the investigations of Kaštela Bay, coastal area of the town of Split (Fig. 1), where many industrial and municipal effluents (still untreated) are discharged into the sea. Kaštela Bay is one of the most threatened areas along the eastern Adriatic coast.

\section{MATERIALS AND METHODS}

The paper presents data on some metals ( $\mathrm{Hg}, \mathrm{MeHg}, \mathrm{As}, \mathrm{Se}, \mathrm{Cu}, \mathrm{Cd}, \mathrm{Sb}$ and $\mathrm{Zn}$ ) in marine organisms (Table 1). Three commercial fish species: striped mullet (Mullus barbatus), hake (Merluccius merluccius) and sea bream (Pagellus erythrinus) were collected by bottom trawl from several characteristic stations in the vicinity of bigger 


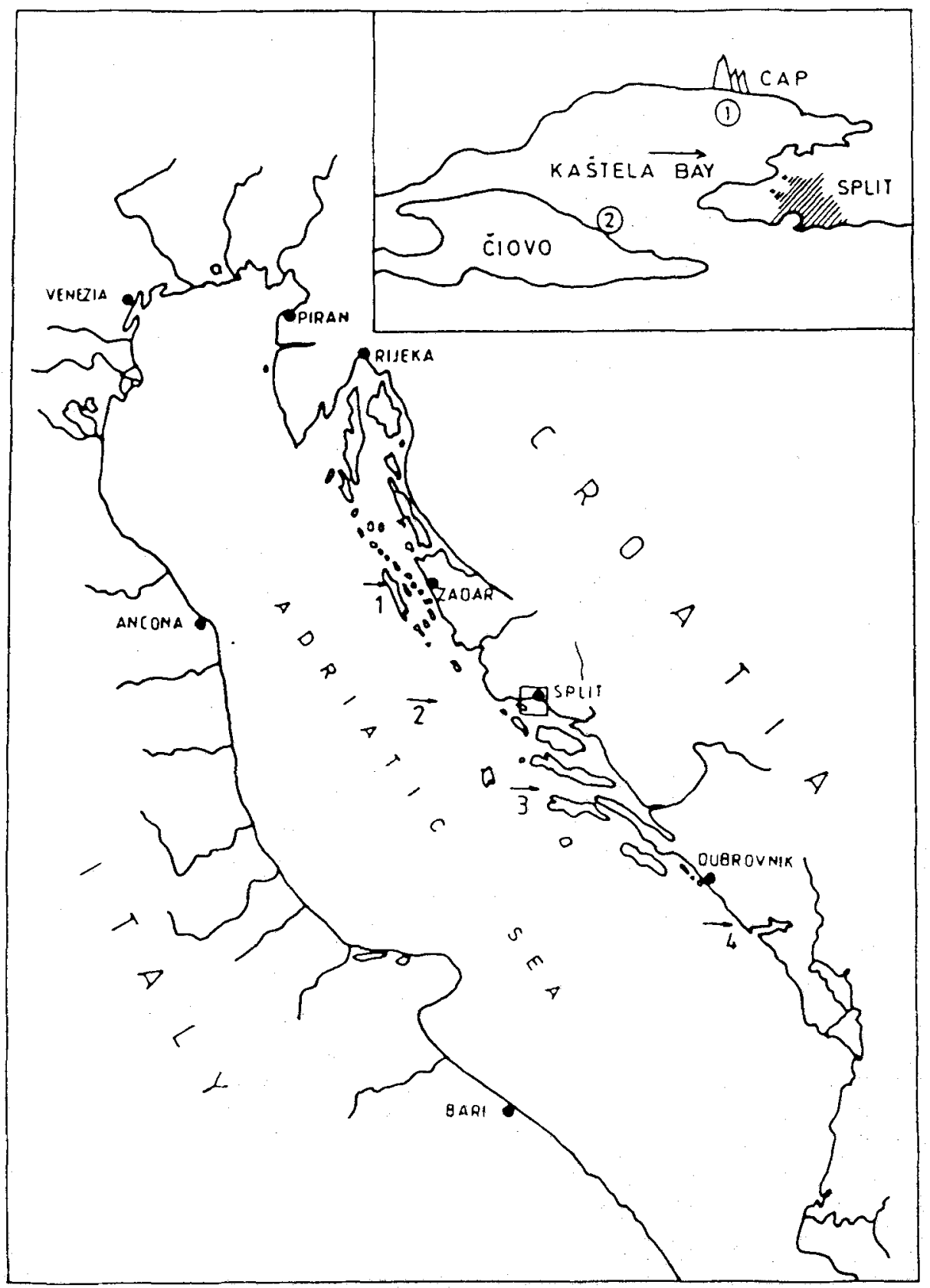

Fig. 1. Study areas 1 and 2: sampling points for Mytilus galloprovincialis. CAP (chlor-alkali plant) 
Table 1. Content of heavy metals in some marine organisms in the open Adriatic Sea (Island of Vis) and in Kaštela Bay (Split area) in $\mathrm{mg} \mathrm{kg}^{-1}, \mathrm{FW},\left(\mathrm{Sb} \mathrm{i} \mu \mathrm{gg}^{-1} \mathrm{FW}\right.$ )

\begin{tabular}{|c|c|c|c|c|c|c|c|}
\hline Organisms & $\mathrm{n}$ & $\mathrm{Hg}$ & $\mathrm{Se}$ & As & $\mathrm{Cu}$ & $\mathrm{Sb}$ & $\mathrm{Zn}$ \\
\hline \multicolumn{8}{|c|}{ KAŠTELA BAY } \\
\hline $\begin{array}{l}\text { Striped mullet } \\
\text { Mullus barbatus } \\
\text { (Trlja)" }\end{array}$ & 25 & $\begin{array}{l}0.52 \\
(0.11)\end{array}$ & $\begin{array}{c}0.33 \\
(0.11)\end{array}$ & $\begin{array}{l}15.8 \\
(2.2)\end{array}$ & $\begin{array}{l}0.48 \\
(0.10)\end{array}$ & $\begin{array}{r}4.52 \\
(1.0)\end{array}$ & $\begin{array}{l}3.19 \\
(0.40)\end{array}$ \\
\hline $\begin{array}{l}\text { Hake } \\
\text { Merluccius } \\
\text { merluccius } \\
\text { (Ostić) }^{\bullet}\end{array}$ & 25 & $\begin{array}{r}0.31 \\
(0.08)\end{array}$ & $\begin{array}{r}0.26 \\
(0.07)\end{array}$ & $\begin{array}{l}11.5 \\
(1.8)\end{array}$ & $\begin{array}{l}0.10 \\
(0.02)\end{array}$ & $\begin{array}{l}2.04 \\
(0.45)\end{array}$ & $\begin{array}{c}1.48 \\
(0.010)\end{array}$ \\
\hline $\begin{array}{l}\text { Sea bream } \\
\text { Pagellus } \\
\text { erythrinus } \\
\text { (Arbun) }^{*}\end{array}$ & 25 & $\begin{array}{l}1.04 \\
(0.60)\end{array}$ & $\begin{array}{l}0.44 \\
(0.04)\end{array}$ & $\begin{array}{r}6.34 \\
(3.2)\end{array}$ & $\begin{array}{l}0.18 \\
(0.03)\end{array}$ & $\begin{array}{l}2.42 \\
(0.60)\end{array}$ & $\begin{array}{l}2.83 \\
(0.25)\end{array}$ \\
\hline \multicolumn{8}{|c|}{ OPEN SEA (VIS ISLAND) } \\
\hline $\begin{array}{l}\text { Striped mullet } \\
\text { Mullus barbatus } \\
\text { (Trlja)* }\end{array}$ & 6 & $\begin{array}{r}0.49 \\
(0.030)\end{array}$ & $\begin{array}{c}0.34 \\
(0.17)\end{array}$ & $\begin{array}{l}3.27 \\
(1.20)\end{array}$ & $\begin{array}{l}0.47 \\
(0.09)\end{array}$ & $\begin{array}{l}1.10 \\
(0.30)\end{array}$ & $\begin{array}{l}2.1 \\
(0.10)\end{array}$ \\
\hline $\begin{array}{l}\text { Hake } \\
\text { Merluccius } \\
\text { merluccius } \\
\text { (Ostić)* }\end{array}$ & 6 & $\begin{array}{r}0.13 \\
(0.020)\end{array}$ & $\begin{array}{l}0.24 \\
(0.10)\end{array}$ & - & - & - & \\
\hline $\begin{array}{l}\text { Sea bream } \\
\text { Pagellus } \\
\text { erythrinus } \\
\text { (Arbun)* }\end{array}$ & 9 & $\begin{array}{r}1.30 \\
(0.010)\end{array}$ & $\begin{array}{c}0.38 \\
(0.12)\end{array}$ & $\begin{array}{c}5.60 \\
(1.70)\end{array}$ & $\begin{array}{c}0.26 \\
(0.05)\end{array}$ & $\begin{array}{c}0.80 \\
(0.25)\end{array}$ & $\begin{array}{r}3.15 \\
(0.60)\end{array}$ \\
\hline
\end{tabular}

urban centres along the eastern Adriatic coast (Zadar, Split, Kaštela Bay and Dubrovnik, Fig. 2; Zvonarić et al., 1988).

Mussel (Mytilus galloprovincialis) samples were collected from two stations in Kaštela Bay (see Fig. 1):

- very close to chlor-alkali plant (CAP) (mussels live on concrete piles and are permanently underwater);

- the island Ciovo, a relatively uncontaminated area (the mussels live on rock in the intertidal zone).

The tissues of mussels (10-20 specimens) were used as a composite sample for analyses. The entire edible parts and various organs (gills, mantle, muscle and visceral organs) of mussel were prepared in the same manner.

Fish samples were identified and length (L) and weight (W) were determined for all specimens. Only the muscle tissue was analysed.

Total mercury was determined by neutron activation analyses (NAA) and cold vapour atomic absorption spectrometry (CV AAS).

Other elements were determined using a double beam AAS, applying a flameless 


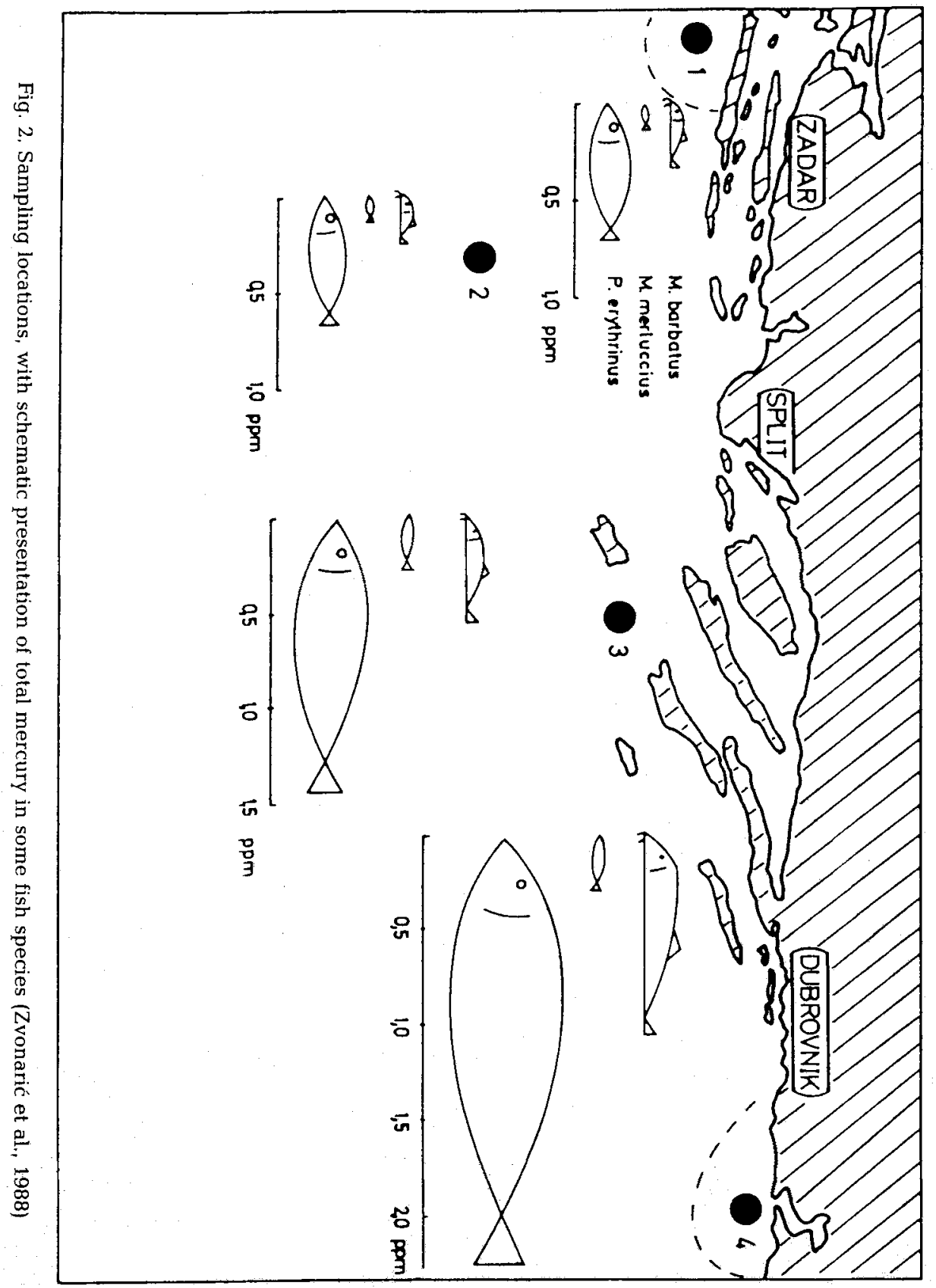


spectrometry. The methods for $\mathrm{Hg}, \mathrm{MeHg}$ and other element determinations were tested by using standard reference materials (NBS SRM 1566, oyster tissue; NBS SRM 1572 , leaves; NBS SRM 1577 A, liver).

Samples were prepared and digested with $\mathrm{HNO}_{3}$, according to the method recommended by UNEP/FAO/IAEA/IOC (Anonymous, 1984). The results are expressed on a fresh weight basis (FW).

\section{RESULTS AND DISCUSSION}

Concentration levels of $\mathrm{Hg}, \mathrm{Se}, \mathrm{As}, \mathrm{Cu}, \mathrm{Sb}$ and $\mathrm{Zn}$ in three fish species studied (striped mullet, hake and sea bream) are presented in Table 1. Results are expressed as mean concentrations. Although there are not many data available for marine organisms, similar values may be found in the Mediterranean (MAP/UNEP Report).

The values found for $\mathrm{Hg}$, As and $\mathrm{Sb}$ in Kaštela Bay are somewhat higher than for organisms collected from the open sea station (Vis Island). The values found here do not exceed the tolerance levels for human consumption recommended by WHO (World Health Organisation, 1973) for fillets.

Table 2 shows the range of total mercury and methyl mercury with a percentage of methylation in the same fish species caught from the open Adriatic Sea and in Kaštela Bay. The probable reason for such high contents of mercury in mentioned species could be a consequence of higher background mercury concentration in the southern part of the Adriatic (natural mercury anomaly) or terrestrial influence from the coast, due to a high percentage of methylation for most of the species analysed (Zvonarić et al., 1988). The highest mercury levels and MeHg levels were found in sea bream, and the lowest in hake. This may be due to the behaviour of this fish ( $P$. erythrinus) which is a demersal fish feeding mainly on benthic organisms.

The rate of bioaccumulation of $\mathrm{Hg}$ in an organism depends not only on the presence of the pollutant, but also on a whole range of biological (age and physiological condition) and environmental factors (temperature, salinity, primary production) (Bryan, 1979; Mikac \& Picer, 1985).

Significant differences of mercury and methylmercury concentrations were found between sampling locations. Levels of $\mathrm{Hg}$ and $\mathrm{MeHg}$ increase towards the southern part of the Adriatic. The values in the south-eastern part are much higher even than in the mercury-polluted area of Kaštela Bay (Table 2). This was an unexpected finding, and these higher concentrations can be attributed to natural sedimentological processes, and submarine springs carrying mafic constituents of igneous and limestone rocks (Paul \& Meischner, 1976; Horvat et al., 1989). The percentage of $\mathrm{MeHg}$ is about $95 \%$, with insignificant differences between species.

Concentrations of total and organic (methyl + dimethyl) mercury, arsenic, cadmium, copper, antimony and zinc in the whole body and internal organs of the mussel Mytilus galloprovincialis are presented in Table 3.

The results obtained so far have shown highly increased $\mathrm{Hg}$ and $\mathrm{MeHg}$ concentrations in the organs of the animals from the area constantly affected by mercury from chlor-alkali plant (CAP), compared to the values from the vicinity of Čiovo island (Fig. 1). Among the isolated organs, the gills contained the highest amount of mercury and zinc in animals from the polluted area of Kaštela Bay, while in the animals collected in a relatively clean area, the highest $\mathrm{Hg}, \mathrm{MeHg}$, $\mathrm{Sb}$ and $\mathrm{Zn}$ content, found in the hepatopan- 
I. Vukadin, T. Zvonarić \& N, Odžak

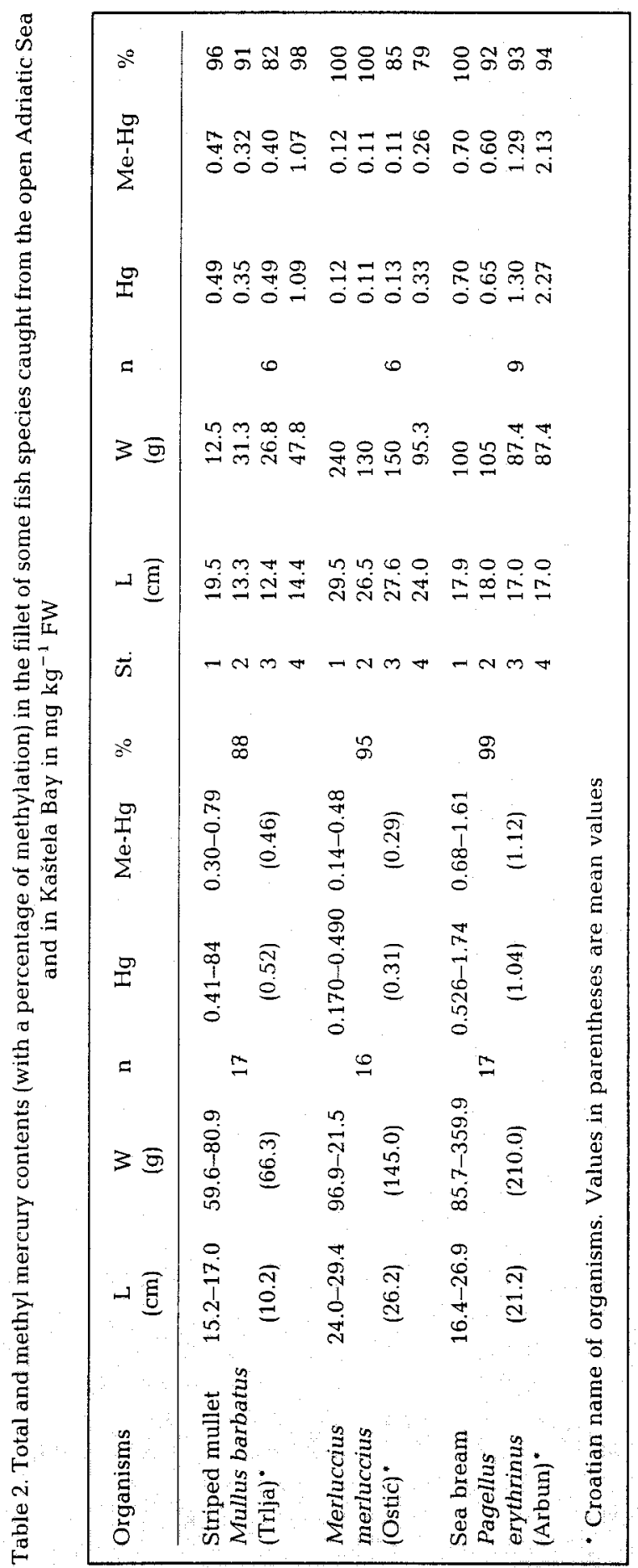


Table 3. Trace elements in composite samples of the mussel Mytilus galloprovincialis (in $\mathrm{mg} \mathrm{kg}^{-1}$ ), $\mathrm{MeHg}$ and $\mathrm{Sb}$ in $\mu \mathrm{g} \mathrm{kg}^{-1} \mathrm{FW}$ ). Values in parentheses are standard deviation

\begin{tabular}{|c|c|c|c|c|c|c|c|c|}
\hline $\begin{array}{l}\text { Station and } \\
\text { samples }\end{array}$ & $\mathrm{n}$ & $\mathrm{Hg}$ & $\mathrm{MeHg}$ & As & $\mathrm{Cd}$ & $\mathrm{Cu}$ & $\mathrm{Sb}$ & $\mathrm{Zn}$ \\
\hline $\begin{array}{l}1 \text { CAP } \\
\text { whole body }\end{array}$ & & $\begin{array}{c}3.32 \\
(1.20)\end{array}$ & $\begin{array}{c}27.2 \\
(10.8)\end{array}$ & $\begin{array}{c}3.20 \\
(0.70)\end{array}$ & $\begin{array}{c}0.15 \\
(0.03)\end{array}$ & $\begin{array}{c}1.65 \\
(0.30)\end{array}$ & $\begin{array}{l}12.96 \\
(2.50)\end{array}$ & $\begin{array}{c}29.4 \\
(3.10)\end{array}$ \\
\hline gills & & $\begin{array}{c}4.53 \\
(0.50)\end{array}$ & $\begin{array}{l}26.8 \\
(6.7)\end{array}$ & $\begin{array}{c}2.10 \\
(0.60)\end{array}$ & $\begin{array}{c}0.10 \\
(0.01)\end{array}$ & $\begin{array}{c}0.99 \\
(0.20)\end{array}$ & $\begin{array}{c}7.25 \\
(1.50)\end{array}$ & $\begin{array}{c}35.8 \\
(3.40)\end{array}$ \\
\hline mantle & 25 & $\begin{array}{c}0.53 \\
(0.12)\end{array}$ & $\begin{array}{c}31.0 \\
(13.0)\end{array}$ & $\begin{array}{c}2.43 \\
(0.55)\end{array}$ & $\begin{array}{c}0.06 \\
(0.01)\end{array}$ & $\begin{array}{c}0.93 \\
(0.010)\end{array}$ & $\begin{array}{c}4.37 \\
(0.70)\end{array}$ & $\begin{array}{l}24.9 \\
(2.2)\end{array}$ \\
\hline hepatopancreas & & $\begin{array}{c}2.46 \\
(1.20)\end{array}$ & $\begin{array}{c}41.6 \\
(19.0)\end{array}$ & $\begin{array}{c}3.56 \\
(0.70)\end{array}$ & $\begin{array}{c}0.29 \\
(0.03)\end{array}$ & $\begin{array}{c}1.98 \\
(0.20)\end{array}$ & $\begin{array}{l}12.71 \\
(3.00)\end{array}$ & $\begin{array}{l}44.6 \\
(3.5)\end{array}$ \\
\hline muscle & & $\begin{array}{c}0.61 \\
(0.25)\end{array}$ & $\begin{array}{c}23.6 \\
(13.6)\end{array}$ & $\begin{array}{c}2.32 \\
(0.40)\end{array}$ & $\begin{array}{c}0.07 \\
(0.01)\end{array}$ & $\begin{array}{c}0.62 \\
(0.010)\end{array}$ & $\begin{array}{c}2.44 \\
(0.45)\end{array}$ & $\begin{array}{l}14.8 \\
(1.4)\end{array}$ \\
\hline $\begin{array}{l}2 \text { CIOVO } \\
\text { whole body }\end{array}$ & & $\begin{array}{c}0.30 \\
(0.12)\end{array}$ & $\begin{array}{l}18.8 \\
(4.2)\end{array}$ & $\begin{array}{c}6.62 \\
(1.20)\end{array}$ & $\begin{array}{c}0.08 \\
(0.01)\end{array}$ & $\begin{array}{c}0.66 \\
(0.02)\end{array}$ & $\begin{array}{c}5.64 \\
(0.75)\end{array}$ & $\begin{array}{c}16.5 \\
(1.00)\end{array}$ \\
\hline gills & & $\begin{array}{c}0.26 \\
(0.06)\end{array}$ & $\begin{array}{l}13.3 \\
(9.5)\end{array}$ & $\begin{array}{c}2.53 \\
(0.40)\end{array}$ & $\begin{array}{c}0.08 \\
(0.01)\end{array}$ & $\begin{array}{c}0.70 \\
(0.03)\end{array}$ & $\begin{array}{c}8.16 \\
(1.00)\end{array}$ & $\begin{array}{c}13.0 \\
(1.10)\end{array}$ \\
\hline mantle & 25 & $\begin{array}{c}0.10 \\
(0.03)\end{array}$ & $\begin{array}{l}14.2 \\
(6.8)\end{array}$ & $\begin{array}{l}4.76 \\
(1.5)\end{array}$ & $\begin{array}{c}0.03 \\
(0.01)\end{array}$ & $\begin{array}{c}0.58 \\
(0.02)\end{array}$ & $\begin{array}{l}12.32 \\
(1.20)\end{array}$ & $\begin{array}{r}8.2 \\
(0.80)\end{array}$ \\
\hline hepatopancreas & & $\begin{array}{c}0.67 \\
(0.42)\end{array}$ & $\begin{array}{c}23.4 \\
(12.0)\end{array}$ & $\begin{array}{c}5.99 \\
(1.20)\end{array}$ & $\begin{array}{c}0.40 \\
(0.02)\end{array}$ & $\begin{array}{c}1.58 \\
(0.03)\end{array}$ & $\begin{array}{l}73.73 \\
(17.0)\end{array}$ & $\begin{array}{l}47.3 \\
(4.0)\end{array}$ \\
\hline muscle & & $\begin{array}{c}0.15 \\
(0.07)\end{array}$ & $\begin{array}{c}21.0 \\
(10.3)\end{array}$ & $\begin{array}{c}3.44 \\
(0.70)\end{array}$ & $\begin{array}{c}0.14 \\
(0.01)\end{array}$ & $\begin{array}{c}0.35 \\
(0.01)\end{array}$ & $\begin{array}{l}12.49 \\
(1.40)\end{array}$ & $\begin{array}{l}21.9 \\
(1.5)\end{array}$ \\
\hline
\end{tabular}

creas, was approximately twice as high as that in other organs. The pattern of distribution of $\mathrm{Hg}$ in the internal organs of the mussel showed that $\mathrm{Hg}$ is accumulated in the digestive gland. The mercury content of the hepatopancreas shows a part of the metals which enters the metabolism.

Figures 3 and 4 present seasonal variations of mercury and methylmercury concentrations in the mussel Mytilus galloprovincialis, from Kaštela Bay, i.e. in the mussel's entire soft part and in different tissues. The values obtained showed good correlation with values for trace metal concentrations in other parts of the Mediterranean as shown by MAP/UNEP Technical Report of 1988 (MAP tech. Rep. Ser. 23).

Most of the maximum values of $\mathrm{Hg}$ were observed in spring (June). We were unable to confirm the statistical significance of organic mercury $(\mathrm{MeHg})$ in the whole body and internal organs of the mussels from the bay (Martinčić, 1981; Vukadin et al., 1984). Reduced metal values in winter are presumably due to the fact that Mytilus galloprovincialis spawn in the middle Adriatic in winter when they lose up to one third of their weight (Šimunović, personal comm.). 

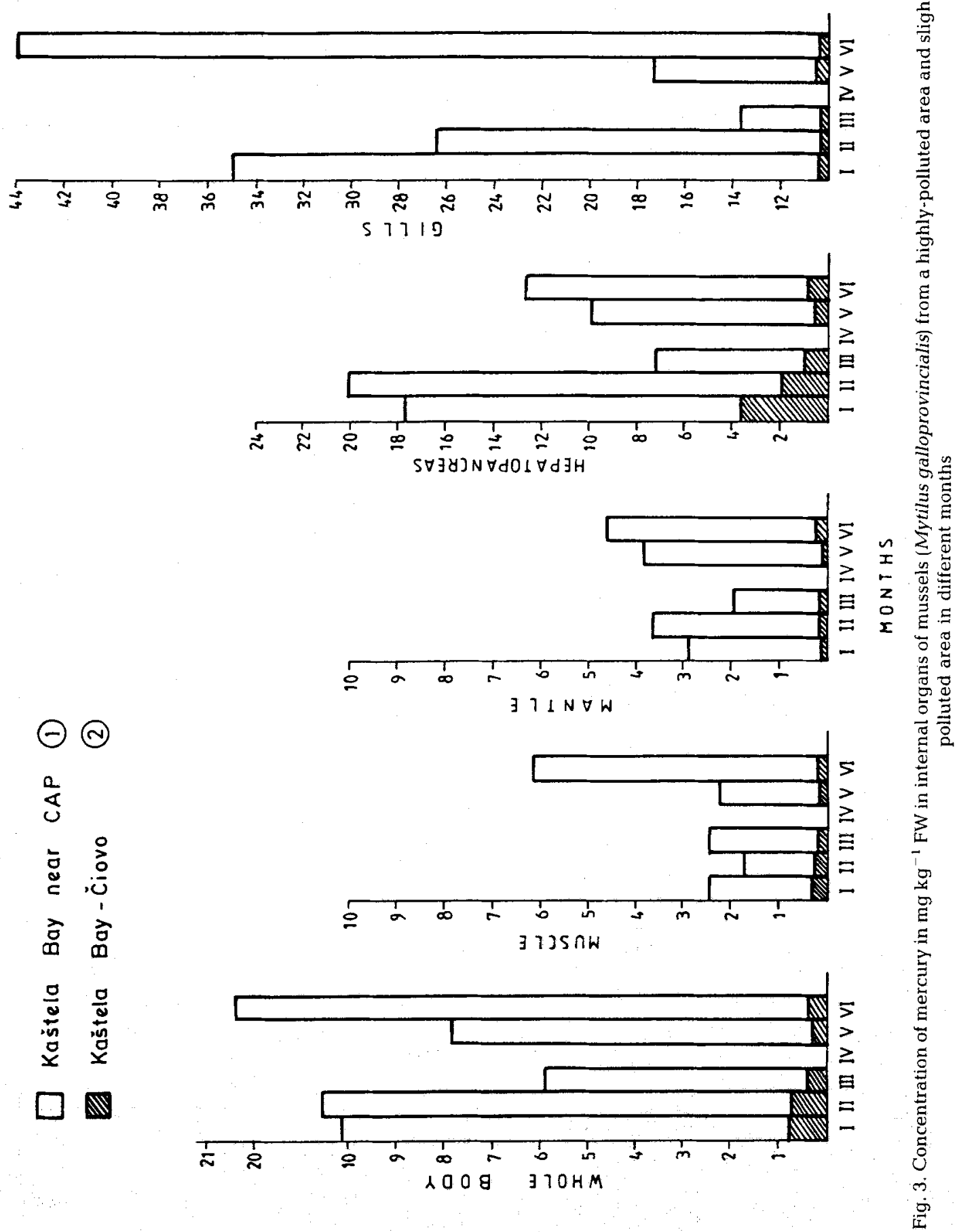


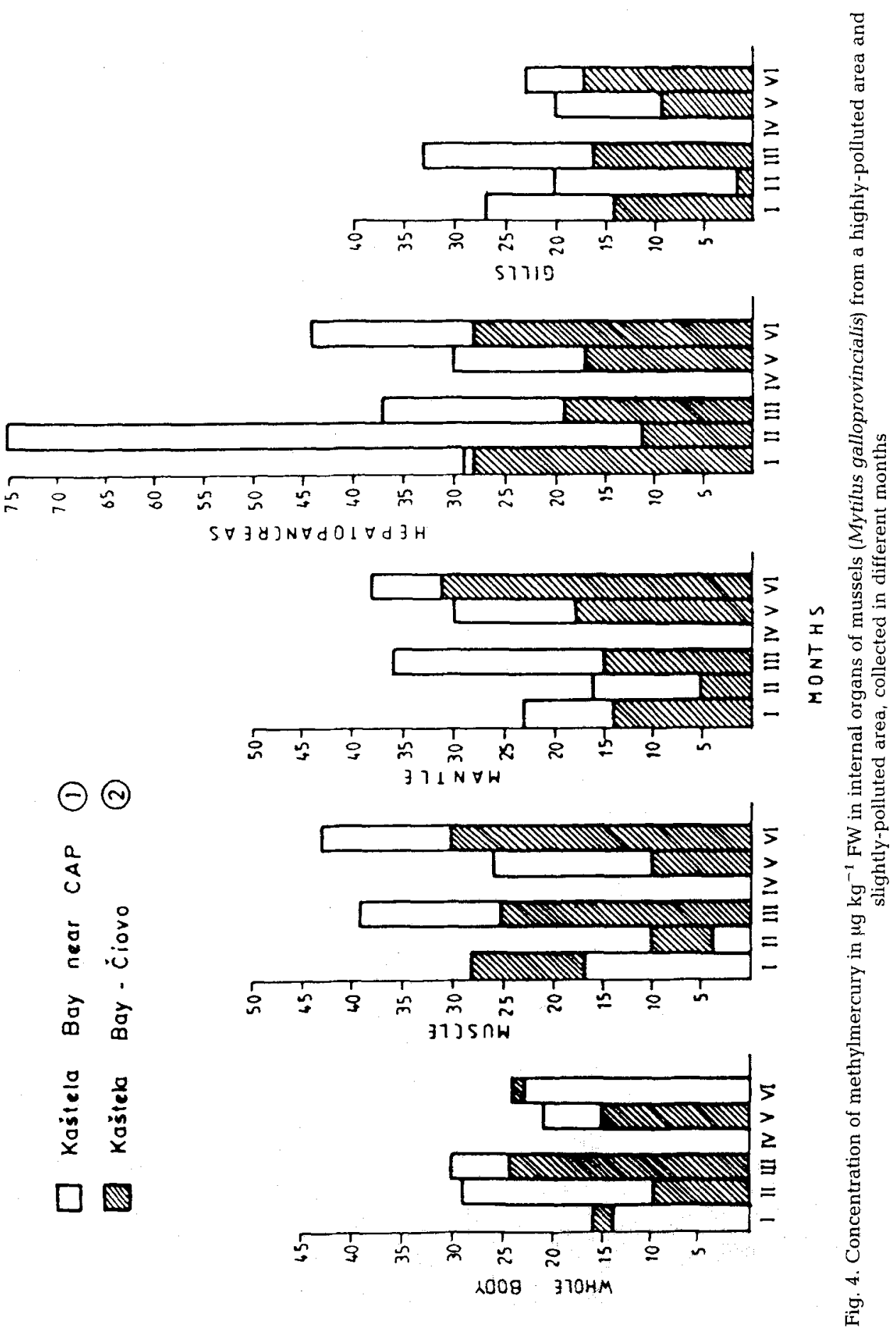




\section{LITERATURE CITED}

Anonymous, 1984. Determination of total cadmium, zinc, lead and copper in selected marine organisms by flameless atomic absorption spectrophotometry. - Ref. Meth. mar. Pollut. Stud. 11, $1-21$.

Bryan, G. W., 1979. Bioaccumulation of marine pollutants. - Phil. Trans. R. Soc. 283, 483-505.

Horvat, M., Zvonarić, T., Stegnar, P., Prosenc, A., Konda, D. \& Sabadin, A., 1989. Relation between total mercury, methylmercury and selenium in fish muscle from Adriatic Sea. In: International conference on heavy metals in the environment, Geneva 1989. Ed. by J. P. Vernet. CEP Consultants, Edinburgh, 370-374.

Martinčić, D., 1981. Trace metal concentrations in the Lim Fjord. Thesis, Univ. Zagreb, 330-335 pp. Mikac, N. \& Picer, M., 1985. Mercury distribution in a polluted area. - Sci. total Environ. 43, $27-39$.

Paul, J. \& Meischner, D., 1976. Heavy metal analysis from sediments of the Adriatic Sea. Senckenberg. marit. $8,91-102$.

Rudd, J. W. M., Furutani, A. \& Turner, M. A., 1980. Mercury methylation in fish intestinal contents. Appl. environ. Microbiol. 40,777-782.

Stegnar, P., Vukadin, I., Smodiš, B., Vakselj, A. \& Prosenc, A., 1981. Trace elements in sediments and organisms from Kaštela Bay. - Journées Etud. Pollut. mar. 5, 595-600.

Vukadin, I., 1980. Heavy metal concentrations in water, sediment and fish in Kaštela Bay. - Acta Adriat. 21, 151-156.

Vukadin, I., Tušek-Znidaršić, M., Byrne, A. R. \& Stegnar, P., 1984. Mercury and methylmercury distribution in the sediment and marine organisms of Kaštela Bay (central Adriatic). - FAO Fish. Rep. 325, 163-168.

Zvonarić, T., Horvat, M. \& Stegnar, P., 1988. Total and methylmercury in some commercial fish species from wider region of middle Adriatic. - Rapp. P.-v. Commn int. Explor. scient. Mer Medit. $31(2), 162$.

World Health Organization (Ed.), 1973. Health hazards in drinking water. Geneva. 